\title{
Coordinate Regulation of Transforming Growth Factor $\beta$ Gene Expression and Cell Proliferation in Hamster Lungs Undergoing Bleomycin-induced Pulmonary Fibrosis
}

\author{
Rajendra Raghow, Pati Irish, and Andrew H. Kang \\ Departments of Pharmacology, Medicine, and Biochemistry, University of Tennessee, \\ and Veterans Administration Medical Center, Memphis, Tennessee 38104
}

\begin{abstract}
The number of mesenchymal cells, as well as their ability to synthesize extracellular matrix (ECM) components, greatly increase in the interstitium of fibrotic lungs. We have previously shown that the transcription of type I procollagen and fibronectin genes in the lungs is preferentially elevated during the early stages of bleomycin-induced pulmonary fibrosis (Raghow, R., S. Lurie, J. M. Seyer, and A. H. Kang. 1985. J. Clin. Invest. 76:1734-1739. Since a cytokine-like transforming growth factor $\beta$ (TGF $\beta$ ) that is capable of enhancing mesenchymal cell proliferation and ECM synthesis could be potentially involved in this process, we investigated the temporal relationship between the regulation of TGF $\beta$ gene transcription and cellular proliferation in the bleomycin-treated hamster lungs. We observed a transient 5-7-fold increase in the accumulation of TGF $\beta$ transcripts, a concomitant 3-4-fold elevation in the cellular proliferation, and 8-10-fold stimulation of DNA synthesis in these lungs; all three parameters peaked around day 10 after bleomycin administration. Based on these results, we conclude that regulation of TGF $\beta$ gene expression may contribute significantly to the early events that lead to bleomycin-induced pulmonary fibrosis.
\end{abstract}

\section{Introduction}

Pulmonary fibrosis, regardless of its etiology, is characterized by increased accumulation of cells and excessive synthesis and deposition of the various extracellular matrix (ECM) ${ }^{1}$ components (1). The biochemical changes in the metabolism of the collagenous and noncollagenous constituents of fibrotic lungs have been extensively investigated using a number of experimental models of pulmonary fibrosis (2-10). Increased synthesis and accumulation of type I collagen has been unequivocally demonstrated in experimentally induced fibrotic lungs of hamsters, mice, and rabbits, as well as in those of humans suffering from idiopathic pulmonary fibrosis $(2,3,10)$. Thus, recent studies also provided evidence for increased rate of

Address reprint requests to Dr. Rajendra Raghow, Research Service, Veterans Administration Medical Center, 1030 Jefferson Avenue, Memphis, TN 38104.

Received for publication 28 October 1988 and in revised form 10 July 1989.

1. Abbreviations used in this paper: ECM, extracellular matrix; TGF, transforming growth factor.

The Journal of Clinical Investigation, Inc.

Volume 84, December 1989, 1836-1842 transcription of genes encoding collagens (type I and III) and fibronectin in the lungs of bleomycin-treated animals $(9,11)$. Neither of these studies formally ruled out the involvement of posttranscriptional regulation (e.g., increased stability of mRNAs or preferential increase in the rate of translation of ECM proteins), and apparent discrepancy between the observed accumulation of ECM proteins and the relative changes in the rate of transcription of their corresponding genes suggests that such posttranscriptional regulatory mechanisms may also be involved in this process.

Although the molecular mechanisms of the altered regulation of ECM genes in lungs undergoing fibrosis are incompletely understood, it is generally thought that a variety of cytokines elaborated by the inflammatory cells recruited in response to tissue injury play a central role in this process. For example, a cytokine-like transforming growth factor $\beta$ (TGF $\beta$ ) is capable of profoundly influencing the biology and ECM phenotype (especially their ability to synthesize collagen and fibronectin) of mesenchymal cells (12-16). Expression of collagen and fibronectin genes by TGF $\beta$ has been shown to be modulated by a complex interplay of transcriptional and posttranscriptional mechanisms (14-18). In addition to elevating the expression of ECM genes, TGF $\beta$ is also a potent chemotactic agent for monocytes and fibroblasts $(12,19)$, as well as a positive modulator of fibroblast proliferation (14). The dramatic fibrotic response to intradermal injection of small amounts of TGF $\beta$ in the newborn mice attests to the possibility that TGF $\beta$ may be one of the key cytokines involved in the cascade of events that leads to fibrosis in vivo (12). Although recently the modulation of TGF $\beta$ gene expression during the early development of mice was elegantly demonstrated (20), to date there are no published accounts of the regulation of TGF $\beta$ in the lungs of either the normal or fibrotic animals. With a long-term goal to understand the molecular mechanisms of bleomycin-induced pulmonary fibrosis, we undertook the present study to investigate the regulation of TGF $\beta$ gene expression in the lungs of hamsters after endotracheal instillation of a single acute dose of bleomycin. An additional goal of these studies was to simultaneously examine the temporal changes in the cell proliferation in situ since it is known that TGF $\beta$ is a potent growth modulator for many cell types, including fibroblasts $(12,21)$. We present evidence to show that there is a five to sevenfold increase in the steady state levels of TGF $\beta$ mRNA relative to total polyadenylated RNA around day 10 after bleomycin treatment. Cytohistological-autoradiographic examination of bleomycin-treated lungs after a pulse of $\left[{ }^{3} \mathrm{H}\right]$ thymidine revealed a coordinate temporal increase in the number of radiolabeled cell nuclei and rate of DNA synthesis, both of which also reached a maximum between 7 and $14 \mathrm{~d}$. Based on these observations, we hypothesize that these two events are related. We further postulate that $\mathrm{TGF} \beta$-mediated cell prolif- 
eration combined with the stimulated transcription of ECM genes play a central role in the process of pulmonary fibrosis.

\section{Methods}

Bleomycin treatment. Bleomycin sulfate (Blenoxane R) was a gift from Bristol Laboratories, Syracuse, NY. The detailed methods for the endotracheal instillation of bleomycin (prepared in sterile saline solution) in the lungs of hamsters have been described previously (9) and were used without any modifications. Pathogen-free Syrian golden hamsters were brought from Charles River Breeding Laboratories, Inc. (Wilmington, MA).

Histology, $\left[{ }^{3} H\right]$ thymidine incorporation and autoradiography of lung sections. At various intervals after bleomycin treatment, a group of five animals and saline-treated controls were anesthetized by intraperitoneal injection of sodium pentabarbital $(0.3 \mathrm{ml} ; 50 \mathrm{mg} / \mathrm{ml} \mathrm{stock}$ solution). The trachea, lungs, and heart were removed and rinsed with PBS. The right inferior lobe from each lung was cut into four equalsized sections, and the superior- and inferior-most corners of the lung were discarded. Tissue slices of lungs were incubated at $37^{\circ} \mathrm{C}$ in $\left[{ }^{3} \mathrm{H}\right]-$ thymidine containing medium $(2.5 \mathrm{ml}$ of DME supplemented with $10 \% \mathrm{FCS}$ and $2.5 \mu \mathrm{Ci}$ of $\left[{ }^{3} \mathrm{H}\right]$ thymidine). After radiolabeling for $4 \mathrm{~h}$, lung tissues were either prepared for autoradiography or processed for determination of ${ }^{3} \mathrm{H}$-incorporation by scintillation counter. TCA-precipitable incorporation of $\left[{ }^{3} \mathrm{H}\right]$ thymidine was determined by homogenizing the tissue slices in 5\% TCA (vol/vol), washing in 95\% ethanol, and counting by scintillation spectrometry (22). Fixed tissue (4\% paraformaldehyde in PBS) was dehydrated in graded ethanol series and embedded in paraffin. Tissue sections ( $5 \mu \mathrm{m}$ thick) were attached to glass coverslips, deparaffinized with xylene, dried, and dehydrated. The dried tissue sections were coated with nuclear track emulsion (NTB-3; Eastman Kodak Co., Rochester, NY), prepared by mixing the melted emulsion with equal volume of $600 \mu \mathrm{M}$ ammonium acetate solution. The emulsion-coated coverslips were air dried for $1 \mathrm{~h}$, packaged in a light-tight box, and stored dried at $4^{\circ} \mathrm{C}$ for $1-2 \mathrm{wk}$. Coverslips were then developed with D-19 (Eastman Kodak Co.) developer (4 min at $23^{\circ} \mathrm{C}$ ), rinsed in tap water, and were fixed with Kodak rapid fix. After washing in running tap water for $15 \mathrm{~min}$, sections were dried and stained with hemotoxylin-eosin stain. The autoradiographic procedures have been described in our previously published work (22).

For quantitative analysis of the labeling index data, 50 consecutive high power fields were examined to analyze $\sim 10-\mu \mathrm{m}^{2}$ area each, representing a total of $\sim 15,000$ cells. A cell containing $>20$ silver grains was counted as positive and data were expressed as the number of radiolabeled nuclei per square millimeter.

Extraction of RNA, oligo-(dT)-cellulose chromatography, and hybridization analysis. Total RNA from the lungs of bleomycin or PBSinstilled hamsters was extracted by guanidine thiocyanate solubilization of rinsed lung tissue and centrifugation of the extract through a cushion of $5.7 \mathrm{M} \mathrm{CsCl}$ (23). The total RNA was fractionated into poly $\mathrm{A}-$ and poly A+ fractions by oligo-(dT)-cellulose columns (24). Aliquots of serial dilution of either total, poly A-, or poly A+ RNA were immobilized on nitrocellulose filters using the slot-blot apparatus (Schleicher \& Schuell, Inc., Keene, NH). Nick-translated plasmids containing the cDNA of either human TGF $\beta$ (25) or chicken $\beta$-actin (26) were used to probe the steady-state levels of the respective mRNAs in these samples. Detailed protocols for the preparation of RNA samples, oligo-(dT)-cellulose chromatography, preparation of radiolabeled probes, and hybridization analyses have been described $(9,15,22$, 27, 28).

Run-off transcription assays. Nuclei (representing 100-150 $\mu \mathrm{g}$ of DNA) from either saline or bleomycin-treated lungs were incubated in a $100-\mu 1$ reaction mix that contained $10 \%$ glycerol, $50 \mathrm{mM}$ Tris- $\mathrm{HCl}$, pH 8.0, $5 \mathrm{mM} \mathrm{MgCl}_{2}, 1 \mathrm{mM}$ each of ATP, GTP, and CTP, and 250 $\mu \mathrm{Ci}$ of $\left[\alpha{ }^{32} \mathrm{P}\right] \mathrm{UTP}$ at $25^{\circ} \mathrm{C}$ for $30 \mathrm{~min}$. Under these conditions, the [ $\left.\alpha-{ }^{32} \mathrm{P}\right]$ UTP showed a linear incorporation for 25-30 min, after which, in some cases, there was an actual decline in the TCA-precipitable radioactivity. An aliquot of nuclei was also incubated with $\alpha$-amanitin $(80 \mu \mathrm{M})$ to determine the specificity of RNA polymerase II-mediated transcription. Radiolabeled RNA was extracted and hybridized to DNA immobilized on nitrocellulose filters. In each case, $10 \mu \mathrm{g}$ of linearized, alkali-denatured, plasmid DNA was immobilized on strips of nitrocellulose and hybridized to nascent transcripts. For determining nonspecific background, $10 \mu \mathrm{g}$ of linearized pBR322 DNA was hybridized to radiolabeled run-off transcripts. Conditions for the preparation of nitrocellulose filters, prehybridization, hybridization at $42^{\circ} \mathrm{C}$, and washing have been described previously $(9,27)$.

Plasmid probes. A full-length chicken $\beta$-actin cDNA cloned in pBR322 (26) was obtained from Dr. Don Cleveland, Johns Hopkins University School of Medicine, Baltimore, MD. A human cDNA encoding TGF $\beta$, cloned in pBR327 (25), was a gift of Dr. Graeme Bell, University of Chicago, Chicago, IL. Supercoiled plasmid DNAs were purified by standard protocols (29), tested for the presence of correctsized insert, and used after nick-translation as described previously (27). The only modification introduced to previously published protocols was the use of nick-translation kit (Bethesda Research Laboratories, Gaithersburg, MD).

\section{Results}

DNA synthesis and cell proliferation. Explant cultures from lungs, either PBS-control or after endotracheal bleomycin treatment, were subjected to two types of analysis to evaluate the potential changes in the cellular proliferation; these included examinations of the mitotic activity by autoradiography of tissue sections and measurement of the uptake of $\left[{ }^{3} \mathrm{H}\right]-$ thymidine into acid-precipitable fraction in lung slices. For direct visualization of mitotic activity the bleomycin-treated lung sections were autoradiographed after labeling lung slices with $\left[{ }^{3} \mathrm{H}\right]$ thymidine. The number of radiolabeled cells containing $>20$ silver grains per nucleus were counted as positive; the number of radiolabeled cells varied little in the lungs of untreated animals at various times after treatment. The number of radiolabeled nuclei in the untreated lungs ranged between 3 and $7 / \mathrm{mm}^{2}$ of the tissue sections examined over a course of $4 \mathrm{wk}$ after saline instillation; the average number of radiolabeled cells was $4.2 / \mathrm{mm}^{2}$ based on quantitation of 250 random sections (data not shown). In contrast, in the bleomycin-treated lungs the number of cells undergoing mitosis, as determined by the criteria established in Methods, increased two- to threefold between day 4 and 6 after bleomycin treatment. The number of radiolabeled cells peaked at day 8 , at which time there were approximately fourfold more numerous radiolabeled cells in bleomycin-treated lungs compared with their untreated counterparts (Fig. 1). Although the number of radiolabeled cells in the bleomycin-treated lungs declined after 2 wk after the treatment, the number of cells with $<20$ grains continued to remain higher (twofold) in bleomycin-treated lungs at all times until the conclusion of this study at $4 \mathrm{wk}$ (Fig. 1). It is of interest to point out that the relative numbers of cells showing $<20$ grains/nucleus were preferentially located in the subpleural areas of the lung (data not shown); the significance of this finding is currently unknown.

Although we attempted to identify the cell types engaged in DNA synthesis as judged by autoradiography, these data should be considered tentative since tissue preservation was not uniform to allow the acquisition of rigorous morphological information to pinpoint cellular identity. We broadly categorized the radiolabeled cells into interstitial, endothelial, and epithelial cell types. At a time when maximum numbers of 


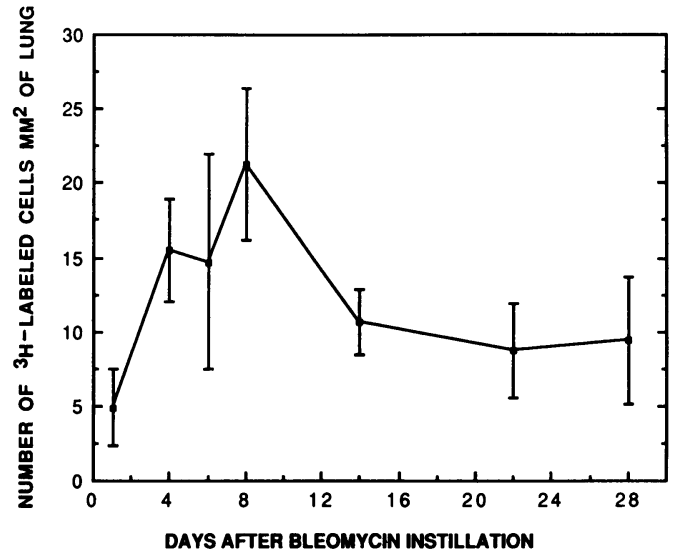

Figure 1. Temporal profiles of cellular proliferation in bleomycintreated hamster lungs. A group of five saline- or bleomycin-instilled hamster lungs were excised at denoted times, tissue slices were radiolabeled with $\left[{ }^{3} \mathrm{H}\right]$ thymidine, and sections were subjected to autoradiography as described in Methods. Average number of ${ }^{3} \mathrm{H}$-labeled cells (containing $>20$ grains) per millimeter square of the lung sections was determined. For quantification of labeling data 50 consecutive high-power fields representing a total of $\sim 15,000$ cells were scored; three randomly chosen areas from a given lung were analyzed and quantitated separately to obtain average number of labeled cells per millimeter square per lung. Average number of positive cells along with standard error bars are presented $(n=15$ : three areas $X$ five lungs). Day 1 represents the day of the endotracheal treatment with either saline or bleomycin.

radiolabeled cells were visible ( $8 \mathrm{~d}$ after bleomycin treatment; Fig. 1), the predominant cell types found to accumulate $\left[{ }^{3} \mathrm{H}\right]-$ thymidine were interstitial cells comprising $62 \pm 9 \%$ of the total radiolabeled cells. The epithelial and endothelial cells were equally represented in remaining $38 \pm 7 \%$ of the labeled cells. It appears therefore that neither cellular damage nor DNA synthesis was exclusively restricted to one or the other cell type, although there was clearly an indication that mainly the interstitial cells were induced to proliferate during postinflammatory tissue repair.

While the direct visualization and quantitation of radiolabeled cells by the histological-autoradiographic method revealed a temporal pattern suggesting a significant change in the mitotic behavior of cells in bleomycin-treated lungs, this technique was somewhat subjective since it was difficult to have completely random sampling due to uneven tissue preservation and qualitative variation in the autoradiographic techniques. Therefore, we attempted to corroborate these data by an alternative method. The lung explants from animals killed at various intervals after bleomycin treatment were incubated in $\left[{ }^{3} \mathrm{H}\right]$ thymidine-containing medium and the TCA-precipitable radioactivity was determined directly in a scintillation spectrometer. The incorporation of $\left[{ }^{3} \mathrm{H}\right]$ thymidine into TCAinsoluble fraction, normalized against total DNA, was determined. Similar data were obtained at all time intervals from the lungs of PBS-control hamsters and the relative change in the TCA-precipitable $\left[{ }^{3} \mathrm{H}\right]$ thymidine incorporation was plotted (Fig. 2). At the time of maximum response, there was nearly eightfold greater incorporation of $\left[{ }^{3} \mathrm{H}\right]$ thymidine in bleomycin-treated lungs at day 10 . Although the rate of DNA synthesis declined subsequently, it remained higher in the bleomycin-treated lungs at all times until the conclusion of this study at $4 \mathrm{wk}$ (Fig. 2). It appears therefore that the overall

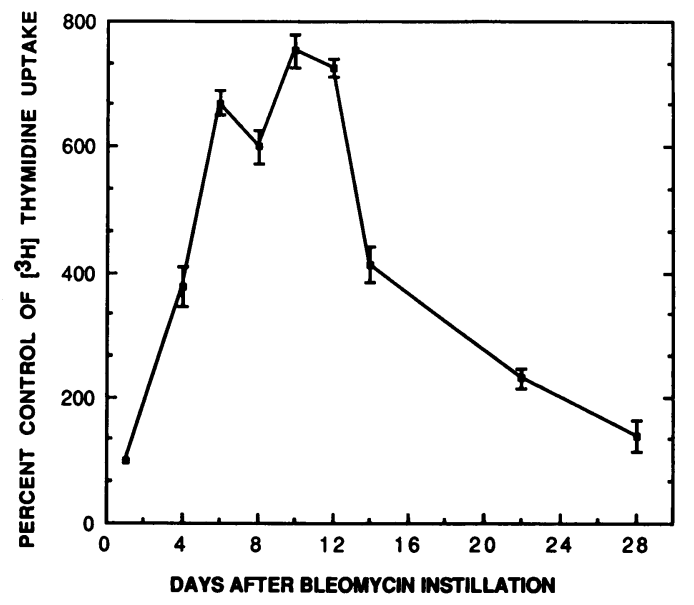

Figure 2. Synthesis of DNA in hamster lungs after endotracheal instillation of bleomycin. A group of five either saline- or bleomycintreated animals were killed at the denoted times and tissue slices were incubated for $1 \mathrm{~h}$ at $37^{\circ} \mathrm{C}$ in media containing $\left[{ }^{3} \mathrm{H}\right]$ thymidine $(2.5 \mu \mathrm{Ci} / \mathrm{ml})$. Radioactivity incorporated into DNA was determined by TCA precipitation and scintillation spectrometry according to protocols described previously (22). Five independent determinations of TCA-precipitable incorporation of $\left[{ }^{3} \mathrm{H}\right]$ thymidine per $\mathrm{mg}$ of total DNA were used to derive these data. Results are expressed as mean percent $\left[{ }^{3} \mathrm{H}\right]$ thymidine incorporation in bleomycin-treated samples compared with saline-treated control with standard error bars $(n=5)$.

pattern of TCA-insoluble incorporation of $\left[{ }^{3} \mathrm{H}\right]$ thymidine essentially resembles the pattern of cell proliferation obtained from autoradiographic visualization of $\left[{ }^{3} \mathrm{H}\right]$ thymidine-labeled cells in the tissue sections (Fig. 1). However, there were clearly quantitative differences. Compared with the autoradiography method, there appears to be a greater net change in the rate of DNA synthesis in the bleomycin-treated lungs as determined by TCA-insoluble $\left[{ }^{3} \mathrm{H}\right]$ thymidine incorporation (three-fivefold versus six to eightfold). Interestingly, the incorporation of $\left[{ }^{3} \mathrm{H}\right]$ thymidine into TCA-precipitable fraction and relative numbers of radiolabeled cells in the bleomycin-treated lungs are quantitatively similar (two- to threefold higher than control) after the first $2 \mathrm{wk}$ following bleomycin treatment (Figs. 1 and 2). We speculate that the autoradiographic method, encompassing the criterion set for a cell to be counted as positive, is not sufficiently sensitive to detect $\left[{ }^{3} \mathrm{H}\right]$ thymidine incorporation that represents unscheduled DNA synthesis (e.g., repair synthesis) initiated in response to the bleomycin-induced breaks in the cellular DNA. However, such incorporation of $\left[{ }^{3} \mathrm{H}\right]$ thymidine into unscheduled DNA synthesis will be detected by the TCA precipitation method.

Temporal changes in the content of TGF $\mathrm{mRNA}$ and transcription of TGF $\beta$ gene in bleomycin-treated lungs. In order to determine the changing dynamics of TGF $\beta$ mRNA in bleomycin-treated lungs, $20 \mu \mathrm{g}$ of total RNA from either saline-treated or experimental lungs was size-fractionated and analyzed by Northern hybridization. Fig. 3 depicts the ethidium bromide-stained agarose gel and the pattern of hybridization to the radiolabeled cDNA probes. Sequential Northern hybridization of blots to TGF $\beta$ and $\beta$-actin probes revealed $\sim 2.6 \mathrm{~kb}$ and $\sim 2.1 \mathrm{~kb}$ transcripts, respectively (Fig. 3). Although the quantitative pattern of how these two mRNAs are regulated in bleomycin-treated lungs cannot be fully appre- 

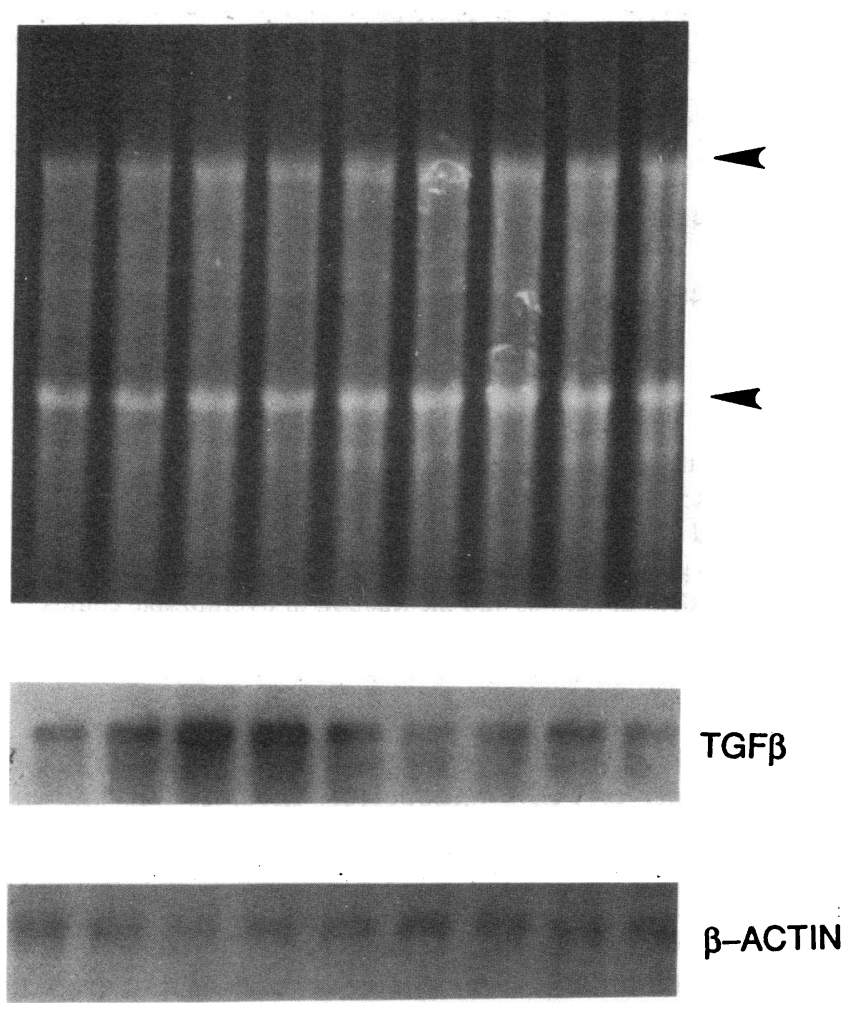

\section{$\begin{array}{lllllllll}C & 4 & 6 & 8 & 10 & 12 & 14 & 22 & 28\end{array}$ \\ DAYS AFTER BLEOMYCIN TREATMENT}

Figure 3. Temporal pattern of accumulation of TGF $\beta$ and $\beta$-actin transcripts in bleomycin-treated hamster lungs. $20 \mu \mathrm{g}$ of total RNA extracted from either saline-treated $(C)$ or bleomycin-instilled lungs at various intervals after treatment was size-fractionated in $1.2 \%$ agarose geis. After electrophoresis, RNA in the gel was stained with ethidium bromide (EtBr); RNA was then transferred to nitrocellulose and sequentially hybridized with radiolabeled cDNA probes. Top panel shows the EtBr-stained gel depicting the major ribosomal RNA species marked by arrows. Autoradiographic image of the TGF $\beta$ transcripts $(\sim 2.6 \mathrm{~kb})$ is shown in the middle panel and the bottom panel depicts the temporal pattern of $\beta$-actin $(\sim 2.1 \mathrm{~kb})$ transcripts in lungs after bleomycin treatment. The detailed experimental protocols for analysis of mRNA by Northern hybridization have been described previously by us (9).

ciated from a single-time exposure of the Northern blots presented in Fig. 3, a transient elevation in the content of TGF $\beta$ mRNA in lungs after 6-8 d of bleomycin treatment can be visualized. To more accurately quantify the relative mRNA content of TGF $\beta$ in the hamster lungs after endotracheal bleomycin treatment, we blotted twofold serial dilutions of either total or poly A+ mRNA (in three separate analyses) extracted from control or bleomycin-treated hamster lungs at various times after treatment. A human TGF $\beta$ cDNA clone was nicktranslated and hybridized to filter-immobilized RNA. As shown in Fig. 4, densitometric quantitation of the hybridization data reveal that there was approximately sixfold greater accumulation of TGF $\beta$ mRNA in bleomycin-treated lungs at the peak time (day 8). The relative steady-state levels of TGF $\beta$ mRNAs varied between four- to sevenfold in lungs $8 \mathrm{~d}$ after bleomycin treatment in three different experiments (data not shown). Steady-state levels of TGF $\beta$ transcripts declined thereafter and returned to levels found in PBS-control lungs (Fig. 4).

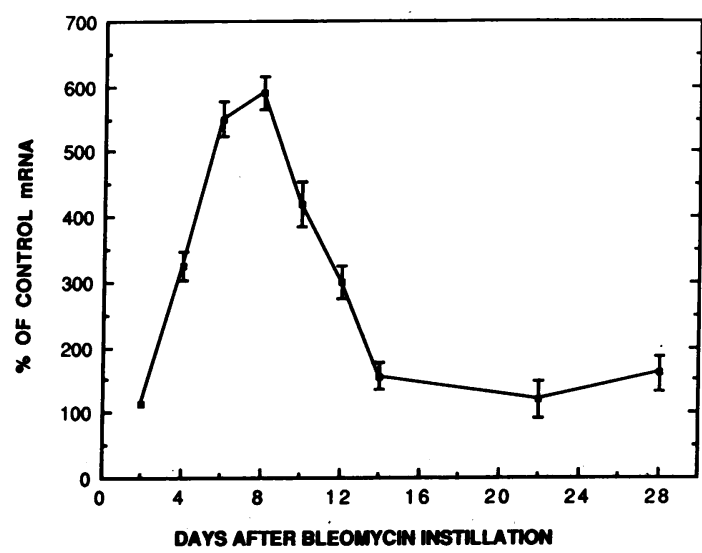

Figure 4. Quantitation of TGF $\beta$ mRNA content in bleomycintreated hamster lungs undergoing pulmonary fibrosis. Equal amounts of poly $\mathrm{A}^{+}$RNA, extracted at denoted intervals from the lungs of control or bleomycin-treated hamsters, were slot-blotted in twofold serial dilutions and hybridized to a nick-translated human TGF $\beta$ cDNA clone. Relative abundance of TGF $\beta$-specific mRNA was quantitated from autoradiographs by laser densitometry. The results are expressed as mean percent change with $\pm \operatorname{SE}(n=5)$ compared with mRNAs in saline-instilled lungs. These data for TGF $\beta$ mRNA were not corrected for changes in the ubiquitously expressed $\beta$-actin mRNA, which were transiently elevated approximately twofold and returned to control values from $14 \mathrm{~d}$ onwards after treatment. The details of these methods have been described previously (9).

Content of TGF $\beta$ transcripts in saline-treated lungs over a 28-d period (duration of the experiment) was found to remain relatively constant; $10-20 \%$ variation between samples was routinely observed (data not shown). To test if these changes specifically reflected perturbations in the steady-state levels of TGF $\beta$ mRNA or were a generalized response of the synthetic capacity of the lungs after bleomycin treatment, these blots were washed and reprobed with $\beta$-actin cDNA. Quantitative analyses of the relative signal density of $\beta$-actin mRNA levels suggested that there was a twofold increase in the steady-state level of this ubiquitous RNA in bleomycin-treated lungs between 7 and $10 \mathrm{~d}$ (data not shown). The increase in the $\beta$-actin mRNA levels observed in the present set of experiments was similar quantitatively with such changes observed previously (9). The increased accumulation of $\beta$ actin-specific mRNA sequences may reflect a generalized increase in the accumulation of total RNA. We and others have previously observed significantly increased (approximately twofold greater than saline controls) accumulation and/or synthesis of RNA in bleomycin-treated cells (9-11). However, the experimental evidence clearly suggests that such global increase in cellular RNA levels cannot account for the proportionately greater accumulation of TGF $\beta$ mRNAs during the inflammatory phase of acute bleomycin injury. When such normalization is taken into account, there is about threefold higher TGF $\beta$ mRNA content in the treated lungs at the time of maximum accumulation (data not shown). In order to determine the mechanisms of the increased levels of TGF $\beta$ transcripts in bleomycin-treated lungs, we directly measured the rates of transcription of TGF $\beta$ and $\beta$-actin genes. A comparison of the rates of transcription of these two genes in saline and bleomycin-treated lung nuclei at day 1 (day of the treatment), day 7 , and day 28 is shown in Table $I$. There appears to be a transient and preferential elevation in the rate of TGF $\beta$ gene transcrip- 
Table I. Run-Off Transcription of TGF $\beta$ and $\beta$-Actin Genes in the Bleomycin-treated Hamster Lung Nuclei

\begin{tabular}{|c|c|c|c|c|c|c|}
\hline \multirow[b]{2}{*}{ Probe } & \multicolumn{2}{|c|}{ Day 1} & \multicolumn{2}{|c|}{ Day 7} & \multicolumn{2}{|c|}{ Day 28} \\
\hline & Control & Bleo & Control & Bleo & Control & Bleo \\
\hline TGF $\beta$ & $37.8 \pm 7.4$ & $(0.84)$ & $36.4 \pm 3.2$ & $141.9 \pm 4.1$ & $(1.2)$ & $51.7 \pm 7.6$ \\
\hline$\beta$-Actin & $112.4 \pm 8.3$ & $108.6 \pm 9.6$ & $117.1 \pm 2.8$ & $148.5 \pm 5.3$ & $136.5 \pm 6.7$ & $121.2 \pm 8.2$ \\
\hline pBR322 & $2.1 \pm 1.2$ & $3.6 \pm 1.5$ & $2.8 \pm 2.1$ & $3.1 \pm 1.9$ & $2.4 \pm 1.7$ & $2.7 \pm 2.3$ \\
\hline
\end{tabular}

Nuclei prepared from lungs of control $(0.5 \mathrm{ml}$ of saline) administered endotracheally or treated ( $1 \mathrm{U}$ of bleomycin in 0.5 of saline instilled as in the control) were incubated in a reaction mix containing all ingredients for run-off transcription. In vitro elongated radiolabeled transcripts $\left(1-2 \times 10^{7}\right)$ from each sample were hybridized to nitrocellulose-bound $5 \mu \mathrm{g}$ of linearized plasmid DNA. Methods for run-off transcription, hybridization, and quantitation by scintillation spectrometry have been described in detail previously (9). Mean average values of ${ }^{32} \mathrm{P}$-labeled nascent transcripts specifically hybridized to a given plasmid DNA were derived from five determinations and the fraction of hybridizable counts is expressed as parts per million with standard error. Background counts (average of $47 \mathrm{cpm}$ ) were subtracted from all values. The ratios of bleomycin/saline control for each time point are shown in the parentheses.

tion in lungs $7 \mathrm{~d}$ after bleomycin treatment. It should be noted that while there was $\sim 25 \%$ change in the rate of transcription of $\beta$-actin gene at day 7 , the transcription of TGF $\beta$ gene was increased 3.8-fold. When the increase in the rate of transcription of TGF $\beta$ gene is normalized against a similar value for $\beta$-actin (perhaps reflecting an increase in the rate of generalized transcription), we obtained a net threefold increased rate of transcription of TGF $\beta$ genes (Table I).

\section{Discussion}

Biosynthesis of type I procollagen and fibronectin in lungs undergoing fibrosis has been studied extensively. In a systematic analysis of the regulation of ECM-related genes, we and others have established the temporal pattern of accumulation of type I procollagen and fibronectin transcripts in bleomycintreated hamsters (9) and mice (11). Based on the increased rates of transcription of collagen and fibronectin genes observed in bleomycin-treated lungs, it was postulated that transcriptional regulation of these genes was responsible for the altered pattern of accumulation of the cognate transcripts in the fibrotic hamster lungs (9). These authors, however, did not formally rule out the involvement of additional posttranscriptional mechanisms known to be involved in collagen gene expression (e.g., alterations in mRNA turnover or translational control; 30) that could also contribute to the altered extracellular matrix of the fibrotic lung. Recent observations (31) have further revealed that the mesenchymal cells in the fibrotic lungs have an altered phenotype, as judged by their ability to be specifically stained with anti-pC antibody, a monoclonal antibody to the $\mathrm{COOH}$-terminal domain of human Pro $\alpha$ 1(I). Since fibroblasts with altered phenotype have been detected at sites of chronic inflammation and repair in other tissues $(32,33)$, it has been postulated that the postinflammatory regenerative processes seen during pulmonary fibrosis closely mimic phenomena elicited during wound healing (34). As a multipotent regulator of mesenchymal cell biology TGF $\beta$ could regulate some of these processes during tissue remodeling (35).

Several in vivo and in vitro studies strongly implicate TGF $\beta$ as a cytokine potentially involved in wound healing and pulmonary fibrosis. For instance, intradermal injection of minute quantities of TGF $\beta$ in newborn mice were shown to result in rapid formation of granulation tissue (12). Such a tissue response to TGF $\beta$ undoubtedly involves well-known properties of this cytokine as a chemoattractant for fibroblasts and monocytes, as a mitogen for fibroblasts $(12,19)$, and a potent inducer of expression of collagen, fibronectin, and glycosaminoglycan genes (12-17). Recent observations have also revealed that TGF $\beta$ significantly accelerates the contraction of collagen matrix in vitro, suggesting an equivalent role for TGF $\beta$ in wound healing (36). Another important relationship of TGF $\beta$ to the ECM metabolism was unraveled recently in various laboratories including our own $(37,38)$. It was found that TGF $\beta$ triggered the synthesis of plasminogen activator inhibitor 1 and its cognate mRNA in lung fibroblasts (37). Thus, in addition to promoting expression of ECM-related genes, TGF $\beta$ can increase the rate of deposition of newly synthesized ECM by modulating the pericellular proteolysis (37).

The present study was undertaken to investigate the potential changes in the TGF $\beta$ gene expression in the lungs of hamsters after administration of a single endotracheal dose of bleomycin. Our results clearly indicate a significant temporal increase in the steady-state accumulation of TGF $\beta$ transcripts during the inflammatory phase of pulmonary fibrosis. The time of maximum increase in the TGF $\beta$-specific transcripts in bleomycin-treated lungs coincided with an increase in the steady-state accumulation of ECM-related transcripts as shown previously (9). Furthermore, a similar relationship was also apparent between the steady-state accumulation of TGF $\beta$ mRNA and the temporal profile representing the rate of cellular DNA synthesis in the bleomycin-treated lungs. While we did not precisely identify the cell types engaged in DNA synthesis and proliferation, it was evident that all three broad categories of cells (e.g., epithelial, endothelial, and interstitial) were involved. However, the predominant proliferating cell type appeared to be the interstitial cells. Although the precise significance of this observation remains speculative, we hypothesize that there is a causal relationship between the rates of cellular DNA synthesis (and cellular proliferation), increased transcription of collagen and fibronectin genes, and TGF $\beta$ gene expression. Although there is apparent qualitative similarity in the profiles of cellular proliferation measured directly (autoradiography) and indirectly (TCA-precipitable $\left[{ }^{3} \mathrm{H}\right]$ thymidine incorporation), the present analyses fail to distinguish 
between the unscheduled DNA synthesis initiated as a result of bleomycin-induced DNA strand scission (39) and scheduled DNA synthesis as a true reflection of the cells in $S$ phase. Clearly, more detailed analyses are needed to resolve this question. Finally, it would be of interest to know which cell type is responsible for the increased transcription of TGF $\beta$ and what mechanisms are involved in the reversible regulation of transcription of TGF $\beta$ and ECM-related genes during fibrosis. Studies addressing these questions involving in situ hybridization techniques are currently in progress.

\section{Acknowledgments}

We wish to dedicate this article to our friend Dr. Murray Heimberg, Van Vleet Professor and Chairman, Department of Pharmacology, University of Tennessee, Memphis, on the occasion of his 65th birthday.

The expert technical assistance of D. Pidikiti and secretarial expertise of K. Pearson are gratefully acknowledged.

These studies were supported by the Veterans Administration(VA) and the National Institutes of Health. Dr. Raghow is an Associate Research Career Scientist of the VA.

\section{References}

1. Turino, G. M. 1980. The assessment of functional impairment in pulmonary interstitial fibrosis. In Pulmonary Diseases and Disorders. A. P. Fishman, editor. McGraw-Hill Book Co., Inc., New York. 725-732.

2. Clark, J. G., C. Kuhn, J. A. McDonald, and R. P. Mecham. 1983. Lung connective tissue. Int. Rev. Connect. Tissue Res. 10:249331.

3. Clark, J. G., J. E. Overton, B. A. Marino, J. Uitto, and B. C. Starcher. 1980. Collagen biosynthesis in bleomycin-induced pulmonary fibrosis in hamsters. J. Lab. Clin. Med. 96:943-953.

4. Madri, J., and H. Furthmayr. 1980. Collagen polymorphism in the lung: an immunohistochemical study of pulmonary fibrosis. Hum. Pathol. 4:353-366.

5. Phan, S. H., R. S. Thrall, and C. Williams. 1981. Bleomycin-induced pulmonary fibrosis: effect of steroid on lung collagen metabolism. Am. Rev. Respir. Dis. 124:428-434.

6. Pickrell, J. 1981. Lung Connective Tissue: Location, Metabolism and Response to Injury. CRC Press, Inc., Boca Raton, FL. 1-224.

7. Goldstein, R. H., E. C. Lucey, C. Franzblau, and G. L. Snider. 1979. Failure of mechanical properties to parallel changes in lung connective tissue composition in bleomycin-induced pulmonary fibrosis. Am. Rev. Respir. Dis. 120:67-73.

8. McCullough, B., J. F. Collins, W. G. Johanson, and F. L. Grover. 1978. Bleomycin-induced diffuse interstitial pulmonary fibrosis in baboons. J. Clin. Invest. 61:79-88.

9. Raghow, R., S. Lurie, J. M. Seyer, and A. H. Kang. 1985. Profiles of steady state levels of messenger RNAs coding for type I procollagen, elastin, and fibronectin in hamster lungs undergoing bleomycin induced interstitial pulmonary fibrosis. J. Clin. Invest. 76:1733-1739.

10. Seyer, J. M., E. T. Hutcheson, and A. H. Kang. 1976. Collagen polymorphism in idiopathic chronic pulmonary fibrosis. J. Clin. Invest. $57: 1498-1507$.

11. Kelley, J., L. Chrin, S. Shull, D. W. Rowe, and K. R. Cutroneo. 1985. Bleomycin selectively elevates mRNA levels for procollagen and fibronectin following acute lung injury. Biochem. Biophys. Res. Commun. 131:836-843.

12. Roberts, A. B., M. B. Sporn, R. K. Assoian, J. M. Smith, N. S. Roche, L. M. Wakefield, U. I. Heine, L. A. Liotta, V. A. Falanga, J. H. Kehrl, and A. S. Fauci. 1986. Transforming growth factor type- $\beta$ : rapid induction of fibrosis and angiogenesis in vivo and stimulation of collagen formation in vitro. Proc. Natl. Acad. Sci. USA. 83:4167-4171.
13. Ignotz, R. A., and J. Massague. 1986. Transforming growth factor- $\beta$ stimulates the expression of fibronectin and collagen and their incorporation into the extracellular matrix. J. Biol. Chem. 261:43374342.

14. Fine, A., and R. H. Goldstein. 1987. The effect of transforming growth factor $\beta$ on cell proliferation and collagen formation by lung fibroblasts. J. Biol. Chem. 262:3897-3902.

15. Raghow, R., A. E. Postlethwaite, J. Keski-Oja, H. L. Moses, and $A . H$. Kang. 1987. Transforming growth factor- $\beta$ increases steady state levels of type I procollagen and fibronectin messenger RNAs posttranscriptionally in cultured human dermal fibroblasts. J. Clin. Invest. 79:1285-1288.

16. Ignotz, R. A., T. Endo, and J. Massague. 1987. Regulation of fibronectin and type I collagen mRNA levels by transforming growth factor $\beta$. J. Biol. Chem. 262:6443-6446.

17. Penttinen, R. P., S. Kobayashi, and P. Bornstein. 1988. Transforming growth factor $\beta$ increases mRNAs for matrix proteins both in the presence and in the absence of change in mRNA stability. Proc. Natl. Acad. Sci. USA. 85:1105-1108.

18. Rossi, P., G. Karsenty, A. B. Roberts, N. S. Roche, M. B. Sporn, and B. deCrombrugghe. 1988. A nuclear factor 1 binding site mediates the transcriptional activation of type I collagen promoter by transforming growth factor $\beta$. Cell. 52:405-414.

19. Postlethwaite, A. E., J. Keski-Oja, H. L. Moses, and A. H. Kang. 1987. Stimulation of the chemotactic migration of human fibroblasts by transforming growth factor- $\beta$. J. Exp. Med. 165:251-256.

20. Heine, U. I., E. F. Munoz, K. C. Flanders, L. R. Ellingsworth, H. Y. Lam, N. L. Thompson, A. B. Roberts, and M. B. Sporn. 1987. Role of transforming growth factor $\beta$ in the development of mouse embryo. J. Cell Biol. 105:2861-2876.

21. Moses, H. L., R. F. Tucker, E. B. Leof, R. J. Coffey, J. Halper, and G. D. Shipley. 1985. Type $\beta$ transforming growth factor is a growth stimulator and a growth inhibitor. Cancer Cells (Cold Spring Harbor). 3:65-71.

22. Raghow, R., A. H. Kang, and D. Pidikiti. 1987. Phenotypic plasticity of extracellular matrix gene expression in cultured hamster lung fibroblasts: regulation of type I procollagen and fibronectin synthesis. J. Biol. Chem. 262:8409-8415.

23. Przybyla, A. E., R. J. MacDonald, J. D. Harding, R. L. Pictet, and W. J. Rutter. 1979. Accumulation of the predominant pancreatic mRNAs during embryonic development. J. Biol. Chem. 254:2159.

24. Aviv, H., and P. Leder. 1972. Purification of biologically active globin messenger RNA by chromatography on oligothymidylic acid cellulose. Proc. Natl. Acad. Sci. USA. 69:1408-1412.

25. Braun, L., J. E. Mead, M. Panzica, R. Mikumo, G. I. Bell, and N. Fausto. 1988. Transforming growth factor $\beta$ mRNA increases during liver regeneration: a possible paracrine mechanism of growth regulation. Proc. Natl. Acad. Sci. USA. 85:1539-1543.

26. Cleveland, D. W., M. A. Lopata, R. J. MacDonald, N. J. Cowan, W. J. Rutter, and M. W. Kirschner. 1980. Number and evolutionary conservation of $\alpha$ and $\beta$-tubulin and cytoplasmic $\beta$ - and $\gamma$ actin genes using specific cloned cDNA probes. Cell. 20:95-105.

27. Raghow, R., D. Gossage, J. M. Seyer, and A. H. Kang. 1984. Transcriptional regulation of type I collagen genes in cultured fibroblasts by a factor isolated from thioacetamide-induced fibrotic rat liver. J. Biol. Chem. 259:12718-12723.

28. Thomas, P. S. 1983. Hybridization of denatured RNA transferred or dotted to nitrocellulose paper. Methods Enzymol. 100:255266.

29. Maniatis, T., E. F. Fritsch, and J. Sambrook. 1982. Large scale isolation of plasmid DNA. In Molecular Cloning. T. Maniatis, E. F. Fritsch, and J. Sambrook, editors. Cold Spring Harbor Laboratory, Cold Spring Harbor, NY. 86-91.

30. Raghow, R., and J. P. Thompson. 1989. Molecular mechanisms of collagen gene expression. Mol. Cell. Biochem. 86:5-18.

31. McDonald, J. A., T. J. Brockelmann, M. L. Mathcke, E. C. 
Crouch, M. Koo, and C. A. Kuhn. 1986. A monoclonal antibody to the carboxy-terminal domain of procollagen type I visualizes collagen synthesizing fibroblasts. Detection of an altered fibroblast phenotype in lungs of patients with pulmonary fibrosis. J. Clin. Invest. 78:12371244.

32. Quinones, F., and E. Crouch. 1986. Biosynthesis of interstitial and basement collagens in pulmonary fibrosis. Am. Rev. Respir. Dis. 134:1163-1171.

33. Kreig, T., J. S. Perlish, R. Fleishmajer, and O. Braun-Falco. 1985. Collagen synthesis in scleroderma: selection of fibroblasts during subcultures. Arch. Dermatol. Res. 277:373-376.

34. Shoshan, S. 1981. Wound healing. Int. Rev. Connect. Tissue Res. 9:1-26.

35. Sporn, M. B., A. B. Roberts, L. M. Wakefield, and R. K. Assoian. 1986. Transformation growth factor $\beta$ : biological function and chemical structure. Science (Wash. DC). 233:532-534.
36. Montesano, R., and L. Orci. 1988. Transforming growth factor $\beta$ stimulates collagen matrix contraction by fibroblasts: implications for wound healing. Proc. Natl. Acad. Sci. USA. 85:4894-4897.

37. Keski-Oja, J., R. Raghow, M. Sawdey, D. J. Loskutoff, A. E. Postlethwaite, A. H. Kang, and H. L. Moses. 1988. Regulation of mRNAs for type I plasminogen activator inhibitor, fibronectin and type I procollagen by transforming growth factor $\beta$ : divergent responses in lung fibroblasts and carcinoma cells. J. Biol. Chem. 263:3111-3115.

38. Saksela, O., D. Moscatelli, and D. B. Rifkin. 1987. The opposing effects of basic fibroblast growth factor and transforming growth factor $\beta$ on the regulation of plasminogen activator activity in capillary endothelial cells. J. Cell Biol. 105:957-963.

39. Murray, V., and R. F. Martin. 1985. The sequence specificity of bleomycin-induced DNA damage in intact cells. J. Biol. Chem. 260:10389-10391. 